\title{
Studies on Morphology and Cytochemistry in Blood Cells of Ayu Plecoglossus altivelis altivelis
}

\author{
Kojin NAKADA ${ }^{1,2) *}$, Kuniyasu FUJISAWA ${ }^{2)}$, Hiroyuki HORIUCHI ${ }^{1)}$ and Shuichi FURUSAWA ${ }^{1)}$ \\ ${ }^{1)}$ Department of Molecular and Applied Bioscience Graduate School of Biosphere Sciences, Hiroshima University, 1-4-4 Kagamiyama, \\ Higashi-hiroshima, Hiroshima 739-8528, Japan \\ 2) Takahashigawa Fisheries Cooperative Association, 52 Teppouchou, Takahashi, Okayama 716-1146, Japan
}

(Received 21 November 2013/Accepted 12 January 2014/Published online in J-STAGE 28 January 2014)

\begin{abstract}
Peripheral blood cells from ayu, Plecoglossus altivelis altivelis, were separated using a density gradient. Blood cells were then smeared using Shandon Cytospin and subjected to cytochemical staining. Blood cells were categorized based on morphological and cytochemical characteristics, and the density fractionation range and nucleus area/cell area ratio were observed. Lymphocytes are distinguished from neutrophils by their basophilic cytoplasm and Golgi-like field. The features of chromatin in thrombocytes are different from those of lymphocytes or neutrophils, but some small neutrophils have similar chromatin. Therefore, it is necessary to perform peroxidase staining to distinguish small neutrophils from thrombocytes. Basophils have large basophilic granules in cytoplasm. Based on density fractionation of blood cells, thrombocytes in the low-density area were separated from other blood cells. Identification of peripheral blood cells from ayu was possible with these staining methods. Monocytes/macrophages from spleen are specifically positive for esterase staining by $\alpha$-naphthyl butyrate. As a result, thrombocytes, lymphocytes, neutrophils, basophils and monocytes/macrophages were identified in smears from peripheral blood or spleen tissue. In this paper, we confirmed that the peripheral blood corpuscles of ayu are able to be identified using the present staining methods.
\end{abstract}

KEY WORDS: ayu, characterization, classification, Percoll, peripheral blood.

doi: 10.1292/jvms.13-0584; J. Vet. Med. Sci. 76(5): 693-704, 2014

Ayu Plecoglossus altivelis altivelis is the main fish stock in fresh-water fisheries around Japan, and culture and release programs have been conducted for many years nationwide. Ayu are produced in aquaculture ponds by artificial fry production and are then released into rivers. In both artificial fry production and adult fish culture, fish can develop various diseases caused by the stress of high-density culture, declining water quality and high water temperature in the summer. Endogenous factors, such as species, genetic background, age and sex, functional deficits due to heredity, immunity and internal secretions and exogenous factors that depend on the environment, such as water temperature and water quality, as well as factors, such as pathogenic microbes and parasites, all play a role in the spread of disease among cultured fish $[12,13,18]$.

In order to reduce the incidence of disease, it is important to both remove the factors responsible and monitor fish health. As a monitoring method, ascertaining changes in immune function via hematological changes are most appropriate. For this purpose, characterization of the differential leucocyte types in the blood of healthy fish was performed in order to serve as basic knowledge and as a marker of patho-

\footnotetext{
*Correspondence to: Furusawa, S., Department of Molecular and Applied Biosciences, Graduate School of Biosphere Sciences, Hiroshima University, 1-4-4 Kagamiyama, Higashi-hiroshima, Hiroshima 739-8528, Japan. e-mail: sfurusa@hiroshima-u.ac.jp (C)2014 The Japanese Society of Veterinary Science

This is an open-access article distributed under the terms of the Creative Commons Attribution Non-Commercial No Derivatives (by-nc-nd) License $<$ http://creativecommons.org/licenses/by-nc-nd/3.0/>.
}

logic changes in specific diseases. Moreover, comparative characterization of hematological research with other fish species is also available [12]. The aim of the present research is to categorize the peripheral blood leucocytes in ayu using morphological characteristics (cell diameter, nucleus diameter and the ratios of nuclear area/cell area), density and enzyme staining.

\section{MATERIALS AND METHODS}

Fish sample: Ayu Plecoglossus altivelis altivelis were hatched and cultured in the $70 \mathrm{t}$ pond at Takahashigawa Fish Farming Laboratory, Shimobara, Soja, Okayama, Japan. Adult fishes (20-30) were maintained in a indoor tank $(1.3 \mathrm{k} l)$ with groundwater at $17-18^{\circ} \mathrm{C}$. Fish were fed once daily with commercial ayu pellets for one week before use in experiments. Samples were collected from two males and two females (mean weight, $74.6 \mathrm{~g}$; mean length, $19.5 \mathrm{~cm}$ ).

Media: PBS: $0.96 \mathrm{~g}$ of PBS (-) powder (Nissui Pharmaceutical Co., Tokyo, Japan) was dissolved in $100 \mathrm{ml}$ of distilled water. $10 \times$ PBS: $9.6 \mathrm{~g}$ of PBS $(-)$ powder was dissolved in $100 \mathrm{~m} l$ of distilled water. 1\% Block Ace PBS; $1 \mathrm{~g}$ of Block Ace (Block Ace Powder; Snow Brand Milk Products KK, Sapporo, Japan) was dissolved in $100 \mathrm{ml}$ of PBS solution. $100 \%$ Percoll solution; 9 parts (v/v) of Percoll (GE Healthcare Bio-Sciences AB, Uppsala, Sweden) was added to 1 part of $10 \times$ PBS. Percoll density gradient medium was prepared by appropriately diluting 100\% Percoll solution with $1 \%$ Block Ace PBS.

Blood sampling: Caudal blood was extracted from ayu with a syringe (Terumo $1 \mathrm{ml}$ tuberculin; Tokyo, Japan) 

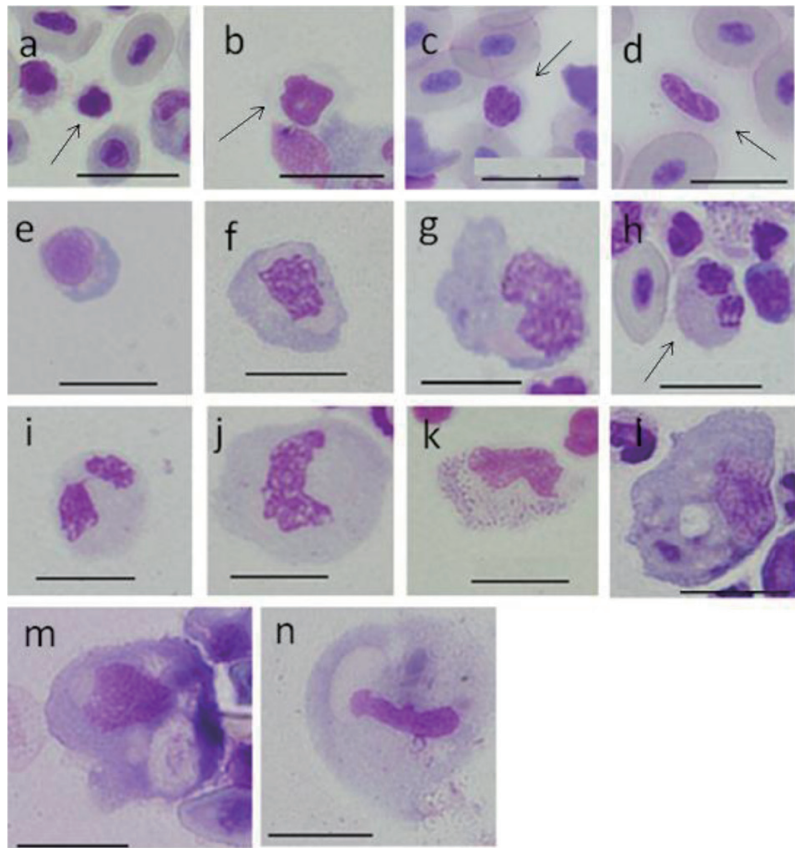

Fig. 1. Cells from peripheral blood (a-1) and spleen (m, n) of ayu, Plecoglossus altivelis altivelis after May-Grünward Giemsa staining (Bar $=10 \mu \mathrm{m})$. a: A1 type (arrow), b: A2 type (arrow), c: Aa type (arrow), d: Ab type (arrow), e: B1 type, f: B2 type, g: B3 type, h: $\mathrm{C} 1$ type (arrow), i: C2 type, j: C3 type, k: D type, 1: E type and m, n: F type

containing $0.1 \mathrm{~m} l$ of heparin (Novoheparin, 1,000 units $/ \mathrm{m} l$; Mochida Pharmaceutical Co., Tokyo, Japan). Blood samples from 4 individuals were mixed in 1 tube.

Splenic cells: Spleens were taken from 4 individuals and were gently homogenized in $1 \times$ BSA-PBS containing a small amount of heparin. Spleen tissue was ground into a slurry using 2 glass microscope slides. Suspensions were then immediately filtered through absorbent cotton in a Pasteur pipette for removal of aggregates and dead tissue to give a blood cell suspension.

Density gradient separation: Percoll density gradient medium from $68 \%$ to $30 \%$ ( $2 \%$ intervals) was stratified in a $15-\mathrm{m} l$ centrifuge tube, and $1-2 \mathrm{~m} l$ of blood or spleen cell suspension was added to the top. The tube was centrifuged at $6^{\circ} \mathrm{C}$ using a cooling centrifuge at $388 \times g$ for $30 \mathrm{~min}$. Each density layer, except for the deposition layer for erythrocytes, was added to a Spitz test tube containing $13 \mathrm{~m} l$ of $1 \%$ BSA-PBS solution, and the suspensions were mixed and centrifuged at $172 \times g$ for $10 \mathrm{~min}$. The upper layer was then removed, and $0.5 \mathrm{~m} l$ of the deposited blood cell layer was suspended with a pipette and mixed with $14 \mathrm{ml}$ of $1 \%$ BSAPBS, followed by centrifugation at $110 \times g$ for $10 \mathrm{~min}$. This procedure was repeated, and the pellet was re-suspended in $0.5 \mathrm{ml}$ of $1 \%$ BSA-PBS. Blood cell count was performed with a Neubauer-type hemocytometer, and after suitable dilution, this was taken as the sample for smears.

Smears: In the sample chamber, 30-50 $\mu \mathrm{l}$ of blood cell suspension was placed, and smears were carried out at 113 $\times g$ for 10 min using Shandon Cytospin 4 (Thermo Electron Co., Pittsburgh, PA, U.S.A.). After centrifugation, the sample was dried with cool air.

Staining: May-Grünwald Giemsa (Muto Pure Chemical Co., Ltd., Tokyo, Japan) (MGG) and Leishman-Giemsa (Merck KgaA, Darmstat, Germany) (LSG) [12] were employed for Romanowsky staining in the morphological study. Peroxidase:3,3' diaminobenzidine method (PO), alkaline phosphatase (ALP), acid phosphatase (ACP), nonspecific esterase: $\alpha$-naphthyl butyrate method (EST- $\alpha$ NB) and periodic acid-Schiff (PAS) were employed for cytochemical study. All of these staining methods were performed with the respective staining kits (Muto Pure Chemical Co., Ltd., Tokyo, Japan). For metachromasia research, toluidine blue (Sigma Aldrich Inc., St. Louis, MO, U.S.A.) staining was employed, and stained smears were rinsed in aqueous solutions of $\mathrm{HCl}$ adjusted to $\mathrm{pH} 1.5,3.0$ and 4.5 [21].

Observation of cells and Photography: Images of blood cells in the stained smears were obtained using a camera (Olympus DP71; Tokyo, Japan) attached to a microscope (Olympus BX51).

Image analysis: The area and diameter (Feret's diameter) of blood cells and their nuclei were calculated using Image $\mathrm{J}$ (National Institutes of Health (NIH), Bethesda, MD, U.S.A.).

With regard to cytochemical activity, cells were divided into 5 types based on the number of positive granules present in the cytoplasm; type 0 (no positive granules) was considered to be negative ( - ), type I (1-5 positive granules) was considered to be slightly positive $( \pm$ ), and types II $-\mathrm{V}$ (more than 5 positive granules) were considered to be positive $(+)$. When cell cytoplasm showed diffusely positive staining, no positive parts of the cytoplasm were considered to be negative (-), faintly positive activity staining was considered to be slightly positive $( \pm)$, and diffuse positive staining throughout the cytoplasm was considered to be positive $(+)$ $[1,11]$.

\section{RESULTS}

Morphological observation of ayu blood cells: Blood cells from the caudal vein and spleen of ayu were collected (except for erythrocytes) by density gradient separation. Blood cells stained with MGG were categorized based on morphological characteristics. The main cells in peripheral blood were divided into three groups; A, B and C. Group A was subdivided into A1 and A2 (Fig. 1a and 1b), while Aa and Ab cells were obtained from a peripheral blood smear prepared using the wedge technique. Group B was subdivided into B1, B2 and B3 (Fig. 1e, 1f and 1g), and group $\mathrm{C}$ was subdivided into $\mathrm{C}$ 1, $\mathrm{C} 2$ and $\mathrm{C} 3$ (Fig. $1 \mathrm{~h}-1 \mathrm{j}$ ).

Group A was composed of small cells with basophilic cytoplasm and nucleus and containing homogeneously packed chromatin. Cells in group B had basophilic blue cytoplasm. Cells in group $\mathrm{C}$ had light blue-gray or light peach-gray cytoplasm, and granules were not apparent. Nuclei showed rough condensed chromatin. Few group D and E cells were seen in peripheral blood (Fig. 1k and 11). In addition, group F cells were seen in the spleen (Fig. 1m and 1n). Cytoplasm in D 
Table 1. Cell area, nucleus area, cell diameter, nucleus diameter and the nucleus area/cell area ratio (N/C ratio) of cells from peripheral blood and spleen of ayu, Plecoglossus altivelis altivelis

\begin{tabular}{|c|c|c|c|c|c|c|c|}
\hline \multirow{2}{*}{$\begin{array}{l}\text { Cell } \\
\text { type }\end{array}$} & \multirow{2}{*}{ Collected part } & \multirow{2}{*}{$\begin{array}{c}\text { No. } \\
\text { Measured }\end{array}$} & $\begin{array}{c}\text { Cell area } \\
\left(\mu \mathrm{m}^{2}\right)\end{array}$ & $\begin{array}{l}\text { Nucleus area } \\
\left(\mu \mathrm{m}^{2}\right)\end{array}$ & $\begin{array}{l}\text { Cell diam. } \\
(\mu \mathrm{m})\end{array}$ & $\begin{array}{l}\text { Nucleus diam. } \\
(\mu \mathrm{m})\end{array}$ & N/Cratio \\
\hline & & & $\begin{array}{c}\text { Range } \\
\text { Mean } \pm \text { SD }\end{array}$ & $\begin{array}{c}\text { Range } \\
\text { Mean } \pm \text { SD }\end{array}$ & $\begin{array}{c}\text { Range } \\
\text { Mean } \pm \text { SD }\end{array}$ & $\begin{array}{c}\text { Range } \\
\text { Mean } \pm \text { SD }\end{array}$ & $\begin{array}{c}\text { Range } \\
\text { Mean } \pm \text { SD }\end{array}$ \\
\hline \multirow{2}{*}{$\mathrm{Aa}$} & \multirow{2}{*}{ Caudal vein ${ }^{\mathrm{a})}$} & \multirow{2}{*}{29} & $17 \sim 28$ & $12 \sim 18$ & $5 \sim 7$ & $4 \sim 6$ & $0.55 \sim 0.81$ \\
\hline & & & $22 \pm 4$ & $14 \pm 2$ & $6 \pm 1$ & $5 \pm 1$ & $0.68 \pm 0.09$ \\
\hline \multirow{2}{*}{$\mathrm{Ab}$} & \multirow{2}{*}{ Caudal vein ${ }^{\mathrm{a})}$} & \multirow{2}{*}{34} & $22 \sim 34$ & $14 \sim 19$ & $6 \sim 10$ & $5 \sim 8$ & $0.53 \sim 0.66$ \\
\hline & & & $27 \pm 3$ & $16 \pm 2$ & $8 \pm 1$ & $7 \pm 1$ & $0.60 \pm 0.04$ \\
\hline \multirow{2}{*}{ A1 } & \multirow{2}{*}{ Caudal vein } & \multirow{2}{*}{85} & $8 \sim 22$ & $4 \sim 14$ & $4 \sim 6$ & $3 \sim 5$ & $0.54 \sim 0.85$ \\
\hline & & & $13 \pm 3$ & $9 \pm 2$ & $5 \pm 0.6$ & $4 \pm 0.5$ & $0.68 \pm 0.07$ \\
\hline \multirow{2}{*}{$\mathrm{A} 2$} & \multirow{2}{*}{ Caudal vein } & \multirow{2}{*}{770} & $16 \sim 59$ & $9 \sim 32$ & $5 \sim 10$ & $4 \sim 8$ & $0.35 \sim 0.78$ \\
\hline & & & $35 \pm 9$ & $18 \pm 4$ & $8 \pm 1$ & $6 \pm 1$ & $0.52 \pm 0.10$ \\
\hline \multirow{2}{*}{ B1 } & \multirow{2}{*}{ Caudal vein } & \multirow{2}{*}{79} & $22 \sim 77$ & $14 \sim 40$ & $6 \sim 12$ & $5 \sim 10$ & $0.37 \sim 0.83$ \\
\hline & & & $44 \pm 11$ & $23 \pm 5$ & $9 \pm 1$ & $7 \pm 1$ & $0.54 \pm 0.09$ \\
\hline \multirow{2}{*}{ B2 } & \multirow{2}{*}{ Caudal vein } & \multirow{2}{*}{54} & $71 \sim 118$ & $27 \sim 43$ & $11 \sim 17$ & $7 \sim 12$ & $0.25 \sim 0.43$ \\
\hline & & & $100 \pm 24$ & $34 \pm 6$ & $14 \pm 2$ & $9 \pm 1$ & $0.35 \pm 0.09$ \\
\hline \multirow{2}{*}{ B3 } & \multirow{2}{*}{ Caudal vein } & \multirow{2}{*}{11} & $124 \sim 147$ & $32 \sim 47$ & $15 \sim 19$ & $8 \sim 11$ & $0.25 \sim 0.36$ \\
\hline & & & $135 \pm 8$ & $39 \pm 4$ & $17 \pm 1$ & $10 \pm 1$ & $0.29 \pm 0.03$ \\
\hline \multirow{2}{*}{$\mathrm{C} 1$} & \multirow{2}{*}{ Caudal vein } & \multirow{2}{*}{50} & $39 \sim 60$ & $13 \sim 25$ & $7 \sim 10$ & $5 \sim 8$ & $0.27 \sim 0.56$ \\
\hline & & & $51 \pm 7$ & $19 \pm 3$ & $9 \pm 1$ & $7 \pm 1$ & $0.38 \pm 0.06$ \\
\hline \multirow{2}{*}{$\mathrm{C} 2$} & \multirow{2}{*}{ Caudal vein } & \multirow{2}{*}{269} & $60 \sim 120$ & $9 \sim 45$ & $10 \sim 21$ & $5 \sim 13$ & $0.14 \sim 0.49$ \\
\hline & & & $94 \pm 16$ & $28 \pm 6$ & $13 \pm 2$ & $9 \pm 1$ & $0.30 \pm 0.05$ \\
\hline \multirow{2}{*}{$\mathrm{C} 3$} & \multirow{2}{*}{ Caudal vein } & 62 & $120 \sim 201$ & $23 \sim 48$ & $13 \sim 22$ & $6 \sim 13$ & $0.15 \sim 0.38$ \\
\hline & & 62 & $140 \pm 15$ & $35 \pm 5$ & $16 \pm 2$ & $10 \pm 1$ & $0.25 \pm 0.04$ \\
\hline $\mathrm{D}$ & Caudal vein & 1 & 109 & 35 & 16 & 10 & 0.32 \\
\hline $\mathrm{E}$ & Caudal vein & 1 & 193 & 48 & 21 & 11 & 0.25 \\
\hline$F$ & snleen & 19 & $124 \sim 308$ & $16 \sim 47$ & $15 \sim 24$ & $6 \sim 12$ & $0.09 \sim 0.21$ \\
\hline $\mathrm{F}$ & spleen & 19 & $216 \pm 46$ & $28 \pm 8$ & $20 \pm 2$ & $9 \pm 2$ & $0.13 \pm 0.04$ \\
\hline
\end{tabular}

a) Smear using Wedge technique.

Table 2. Percentage of various cells in peripheral blood of Ayu, Plecoglossus altivelis altivelis

\begin{tabular}{cr}
\hline Cell type & $\begin{array}{r}\text { percentage } \\
\text { Mean } \pm \text { SD }\end{array}$ \\
\hline A1 & $3.6 \pm 0.9$ \\
A2 & $49.1 \pm 6.9$ \\
B1 & $6.2 \pm 3.7$ \\
B2 & $5.0 \pm 3.1$ \\
B3 & $0.8 \pm 0.5$ \\
C1 & $16.5 \pm 6.6$ \\
C2 & $18.6 \pm 3.4$ \\
C3 & $0.3 \pm 0.2$ \\
D & $0.03 \pm \mathrm{nc}$ \\
E & $0.03 \pm \mathrm{nc}$ \\
\hline
\end{tabular}

nc: no calculate.

cells showed large blue-purple granules. Group E cells were the largest and possessed vesicles/vacuoles and inclusions, and the nucleus was kidney-shaped with linearly packed chromatin. The morphological characteristics of group $\mathrm{F}$ cells were almost the same of those of E cells. The ratio of nucleus area to cell area (N/C) was calculated using more than 1,000 cells from groups A, B and C, as well as some D,
Table 3. Production of segmented (bilobed nuclei) cells by subgroup of $\mathrm{C}$ cells from ayu, ,Plecoglossus altivelis altivelis

\begin{tabular}{cc}
\hline Type & $\begin{array}{c}\text { Appearance (\%) } \\
\text { Mean } \pm \mathrm{SD}\end{array}$ \\
\hline $\mathrm{C} 1$ & $16 \pm 8$ \\
$\mathrm{C} 2$ & $13 \pm 5$ \\
$\mathrm{C} 3$ & $27 \pm 43$ \\
\hline
\end{tabular}

E and F cells. Based on seven 50-60 g fish, the appearance ratios for each group of peripheral white blood cells were calculated using more than 400 cells.

Group A cells: A1 type cells were small, round or spindleshaped with an area of 8-22 (13 \pm 3$) \mu \mathrm{m}^{2}$ and a diameter of 4-6 (5 \pm 0.6$) \mu \mathrm{m}$ and constituting $3.8 \pm 0.9 \%$ of total white blood cells. The cytoplasm was gray or light blue-purple on Romanowsky staining, but there were also cells with very narrow cytoplasm. The N/C ratio was $0.68 \pm 0.09$. The nucleus was dark purplish-red and spindle-shaped with homogeneously packed chromatin. It was observed that most A1 cells were aggregated (Fig. 1a) (Tables 1 and 2).

A2 type cells were round or oval with an area of 16-59 (35 
Table 4. Percentage of blood cells from ayu, Plecoglossus altivelis altivelis, separated by Percoll density gradient

\begin{tabular}{|c|c|c|c|c|c|c|c|c|c|c|c|}
\hline \multirow{2}{*}{$\%$ of percoll } & \multirow{2}{*}{$\begin{array}{l}\text { Specific } \\
\text { gravity }\end{array}$} & \multicolumn{10}{|c|}{ Blood cell type } \\
\hline & & A1 & A2 & B1 & B2 & B3 & $\mathrm{C} 1$ & $\mathrm{C} 2$ & $\mathrm{C} 3$ & $\mathrm{D}$ & $\mathrm{E}$ \\
\hline 32 & 1.042 & 5 & 64 & 0 & 2 & 0 & 3 & 7 & 20 & 0 & 0 \\
\hline 34 & 1.045 & 9 & 52 & 1 & 2 & 0 & 0 & 16 & 20 & 0 & 0 \\
\hline 36 & 1.047 & 9 & 88 & 1 & 0 & 0 & 0 & 2 & 0 & 0 & 0 \\
\hline 38 & 1.049 & 13 & 81 & 4 & 0 & 0 & 1 & 1 & 0 & 0 & 0 \\
\hline 40 & 1.052 & 11 & 61 & 17 & 1 & 0 & 0 & 6 & 4 & 0 & 0 \\
\hline 42 & 1.054 & 1 & 71 & 11 & 1 & 0 & 0 & 10 & 7 & 0 & 0 \\
\hline 44 & 1.056 & 11 & 43 & 15 & 2 & 3 & 6 & 13 & 5 & 0 & 0 \\
\hline 46 & 1.059 & 0 & 9 & 25 & 5 & 3 & 9 & 24 & 25 & 0 & 0 \\
\hline 48 & 1.061 & 0 & 1 & 24 & 6 & 5 & 2 & 45 & 16 & 0 & 0 \\
\hline 50 & 1.063 & 0 & 10 & 40 & 5 & 0 & 2 & 29 & 14 & 0 & $<0.02^{*}$ \\
\hline 52 & 1.066 & 0 & 0 & 0 & 5 & 0 & 1 & 70 & 25 & $<0.02 *$ & 0 \\
\hline 54 & 1.068 & 0 & 0 & 0 & 3 & 0 & 0 & 42 & 55 & 0 & 0 \\
\hline 56 & 1.070 & 0 & 0 & 0 & 4 & 3 & 7 & 55 & 31 & 0 & 0 \\
\hline 58 & 1.073 & 0 & 1 & 4 & 6 & 0 & 17 & 62 & 10 & 0 & 0 \\
\hline 60 & 1.075 & 0 & 0 & 14 & 9 & 0 & 8 & 45 & 23 & 0 & 0 \\
\hline
\end{tabular}

* Count cell numbers: $>5,000$ cells.

$\pm 9) \mu \mathrm{m}^{2}$ and a diameter of $5-10(8 \pm 1) \mu \mathrm{m}$ and constituting $49.1 \pm 6.9 \%$ of total blood cells. The $\mathrm{N} / \mathrm{C}$ ratio was $0.52 \pm 0.1$. The cytoplasm of A2 cells was gray or light blue-purple or light blue and tended to have cytoplasmic pseudopodia. Unlike A1 type cells, the A2 nucleus was light purplish-red, but with homogeneously packed chromatin, similarly to A1 type cells. Nuclei had many shape forms, including round, kidneyshaped and horseshoe-shaped (Fig. 1b) (Tables 1 and 2).

$\mathrm{Aa}$ and $\mathrm{Ab}$ type cells were observed on smears obtained using the Wedge method.

Aa type cells were round or bean-shaped with an area of $17-28(22 \pm 4) \mu \mathrm{m}^{2}$ and a diameter of 5-7 $(6 \pm 1) \mu \mathrm{m}$. The $\mathrm{N} / \mathrm{C}$ ratio was $0.68 \pm 0.09$. Cytoplasm in Aa was colorless, gray or light blue-purple. The Aa nucleus was purplish-red with faint roughly condensed chromatin, and the end included a nick (Fig. 1c) (Tables 1 and 2).

$\mathrm{Ab}$ type cells were spike-shaped with an area of 22-34 $(27 \pm 3) \mu \mathrm{m}^{2}$ and a diameter of $6-10(8 \pm 1) \mu \mathrm{m}$. N/C ratio was $0.60 \pm 0.04$. The cytoplasm of Aa was gray or light bluepurple. The Ab nucleus was light purplish-red with faint rough condensed chromatin (Fig. 1d) (Tables 1 and 2).

Group B cells: B1 type cells were round, oval or beanshaped with an area of $22-77(44 \pm 11) \mu \mathrm{m}^{2}$ and a diameter of 6-12 $(9 \pm 1) \mu \mathrm{m}$ and constituting $6.2 \pm 3.7 \%$ of total white blood cells. The N/C ratio was $0.54 \pm 0.09$. Basophilic cytoplasm was blue or light blue on Romanowsky staining, but the Golgi-like field near the nucleus was gray or a weak peach color. Cytoplasmic pseudopodia were not observed in $\mathrm{B} 1$ cells. The eccentric nucleus was round or oval with rough condensed chromatin (Fig. 1e) (Tables 1 and 2). For convenience, B2 and B3 were divided based on area; B2 cells had an area of $71-118(100 \pm 24) \mu \mathrm{m}^{2}$ and a diameter of $11-17$ (14 \pm 2$) \mu \mathrm{m}$ and constituted $5.0 \pm 3.1 \%$ of total white blood cells, while B3 cells had an area of 124-147 (135 \pm 8$) \mu \mathrm{m}^{2}$ and a diameter of 15-19 $(17 \pm 1) \mu \mathrm{m}$ and constituted $0.8 \pm$ $0.5 \%$ of total blood cells. B2 and B3 cells were round or spindle-shaped, and some cells with cytoplasmic pseudopo- dia were seen. The cytoplasm was blue-gray or light blue, and the Golgi-like field had some colorless vesicles. Nuclei were kidney-shaped, horseshoe-shaped or infinity-shaped with rough condensed chromatin (Fig. 1f and 1g) (Tables 1 and 2).

Group C cells: All cells in group C had the same morphological features. C cells had an area of 36-201 $\mu \mathrm{m}^{2}(7-21 \mu \mathrm{m}$ in diameter) and were divided into $\mathrm{C} 1: 39-60(51 \pm 7) \mu \mathrm{m}^{2}$, C2: 60-120 (94 \pm 16$) \mu \mathrm{m}^{2}$ and C3: $120-201(140 \pm 15) \mu \mathrm{m}^{2}$. $\mathrm{C} 1, \mathrm{C} 2$ and $\mathrm{C} 3$ constituted $16.5 \pm 6.6 \%, 18.6 \pm 3.4 \%$ and $0.3 \pm 0.2 \%$ of total white blood cells, respectively. C cells were round or oval, cytoplasm was light blue-gray or light peach-gray, and granules were invisible. Nuclei were round, spindle-shaped, kidney-shaped or rod-shaped with rough condensed chromatin, but the nuclei of $\mathrm{C} 1$ cells included faint rough condensed chromatin (Fig. 1h-1j) (Tables 1 and 2). Cells with a constricted portion of one-third the nuclear width or less were considered to be bilobed. Bilobed nuclei were present in approximately $20 \%$ of C cells (Table 3 ).

Group D cells: There was one D cell in 1,853 observed cells. This cell was oval and had an area of $109 \mu \mathrm{m}^{2}(14 \mu \mathrm{m}$ in diameter). The $\mathrm{N} / \mathrm{C}$ ratio was 0.32 . Cytoplasm was light blue-gray and light red in parts with large blue- purple granules of $0.3-0.4 \mu \mathrm{m}$. The D cell was observed only in the fraction of specific gravity (SG) 1.066. The nucleus was redpurple and was kidney-shaped and contained the same large blue-purple granules as in cytoplasm. The chromatin net was unclear (Fig. 1k) (Tables 1 and 2).

Group E cells: There was also one E cell in 1,853 observed cells. E cells were the largest oval cells with pseudopodia in peripheral white blood cells with an area of 193 $\mu \mathrm{m}^{2}$ (21 $\mu \mathrm{m}$ in diameter). The $\mathrm{N} / \mathrm{C}$ ratio was 0.25 . The $\mathrm{E}$ cell was observed only in the fraction of SG 1.063. Cytoplasm was light blue-gray with scattered blue granules, and some vesicles/vacuoles of about $3 \mu \mathrm{m}$ and dark red-purple stained inclusions were observed. Nuclei were kidney-shaped with linear packed chromatin (Fig. 11) (Tables 1 and 2). 

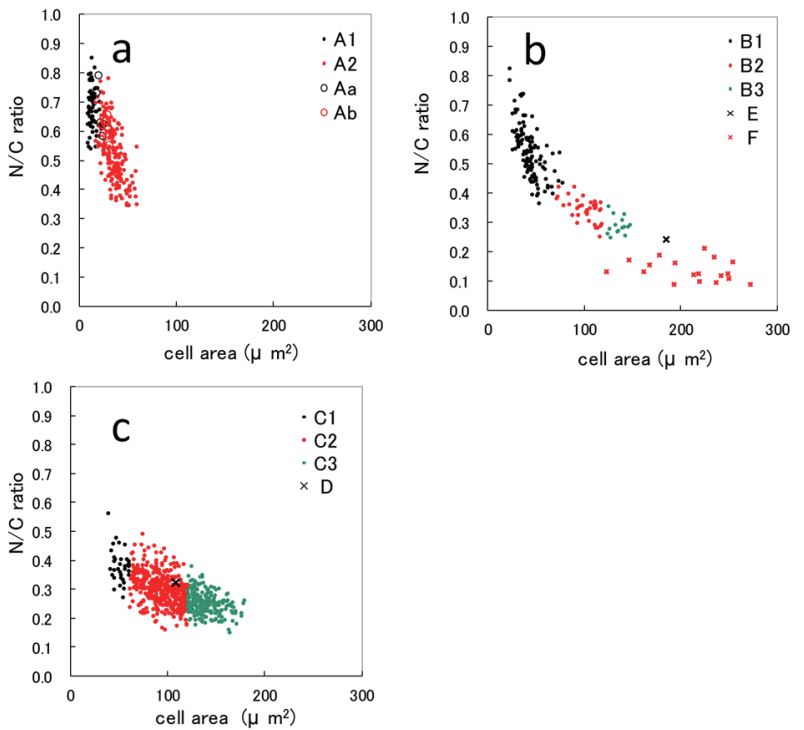

Fig. 2. Relationship between cell area and nucleus area/cell area (N/C) ratio in peripheral blood cells and splenic tissue from ayu Plecoglossu altivelis altivelis. a: A1 type, A2 type, Aa type and Ab type cells. b: B1 type, B2 type, B3 type, E type and F type cells. c: $\mathrm{C} 1$ type, $\mathrm{C} 2$ type, $\mathrm{C} 3$ type and $\mathrm{D}$ type cells.
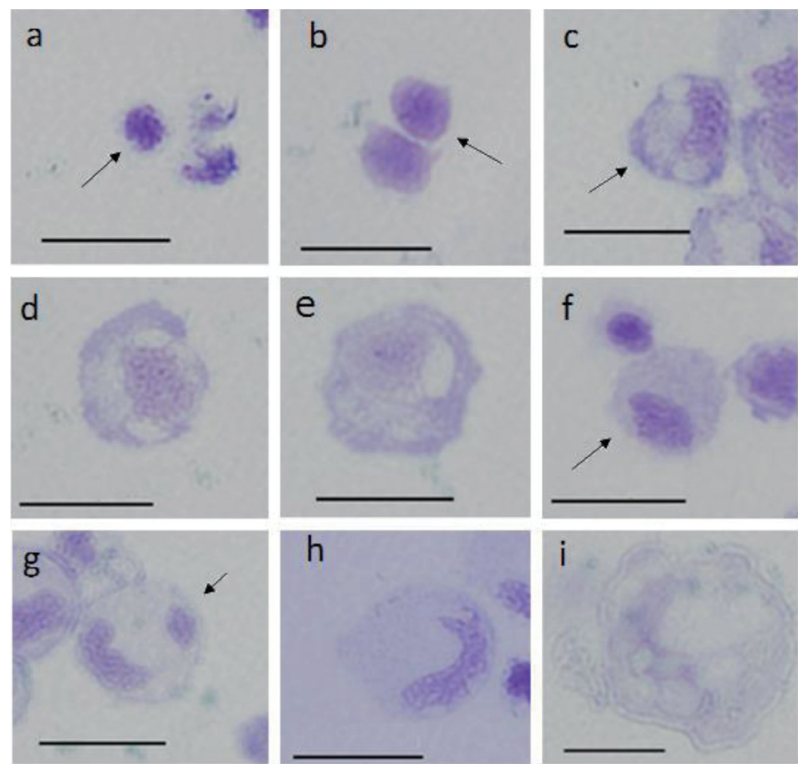

Fig. 4. Cells from peripheral blood (a-h) and spleen (i) of ayu, Plecoglossus altivelis altivelis, after toluidine blue staining (rinsed in water at $\mathrm{pH} 4.5$ ). $\mathrm{Bar}=10 \mu \mathrm{m}$, a: A1 type (arrow), b: A2 type (arrow), c: B1 type (arrow), d: B2 type, e: B3 type, f: C1 type (arrow), g: C2 type (arrow), h: C3 type and i: F type.

Group F cells: F cells were the largest cells in the spleen of ayu and were round, oval or amoeboid in shape with pseudopodia and an area of 124-308 $(216 \pm 46) \mu \mathrm{m}^{2}$ and a diameter of 15-24 (20 \pm 2$) \mu \mathrm{m}$. The N/C ratio was 0.09-0.21 (0.13
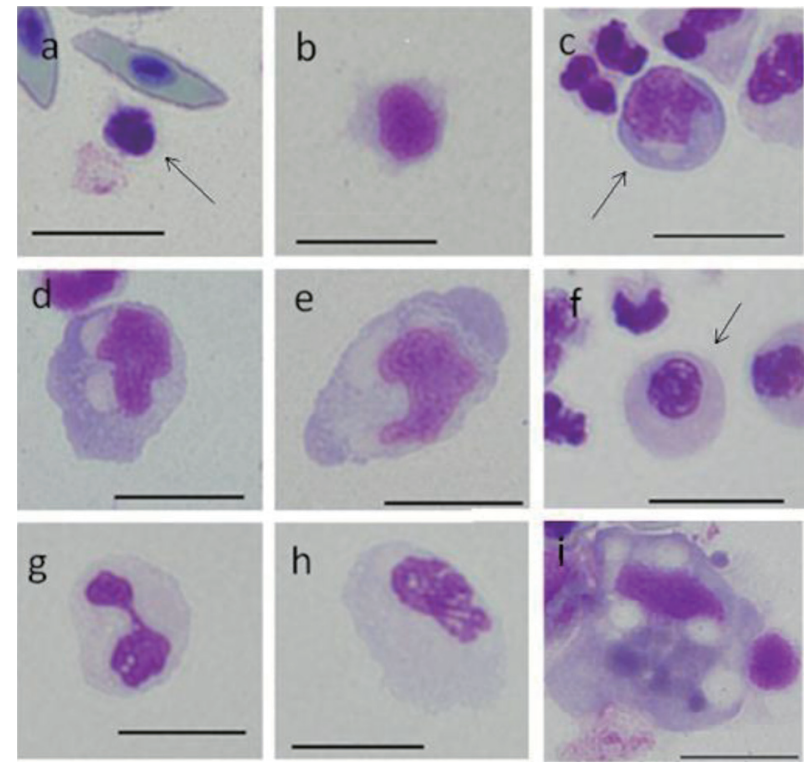

Fig. 3. Cells from peripheral blood (a-h) and spleen (i) of ayu, Plecoglossus altivelis altivelis, after Leishman-Giemsa staining. Bar $=10$ $\mu \mathrm{m}$, a: A1 type (arrow), b: A2 type, c: B1 type (arrow), d: B2 type, e: $\mathrm{B} 3$ type, f: $\mathrm{C} 1$ type (arrow), g: C2 type, h: C3 type and i: F type.
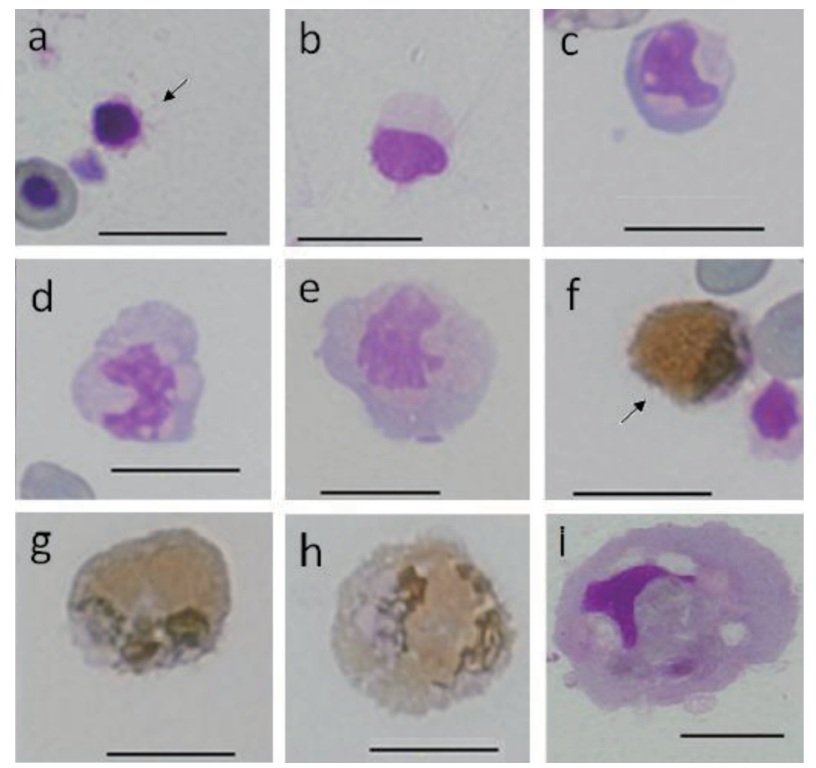

Fig. 5. Cells from peripheral blood (a-h) and spleen (i) of ayu, Plecoglossus altivelis altivelis, after peroxidase (3,3' diaminobenzidine method)-Giemsa staining. Bar=10 $\mu \mathrm{m}$, a: A1 type (arrow), b: A2 type, c: B1 type, d: B2 type, e: B3 type, f: C1 type (arrow), g: C2 type, h: $\mathrm{C} 3$ type and i: F type.

\pm 0.04 ) (Table 1). The morphological characteristics of $F$ cells were almost the same as those of E cells. Phagocytosed erythrocytes (Fig. 1m), vesicles/vacuoles and black-blue or black-brown inclusions were seen in the cytoplasm of F cell. 

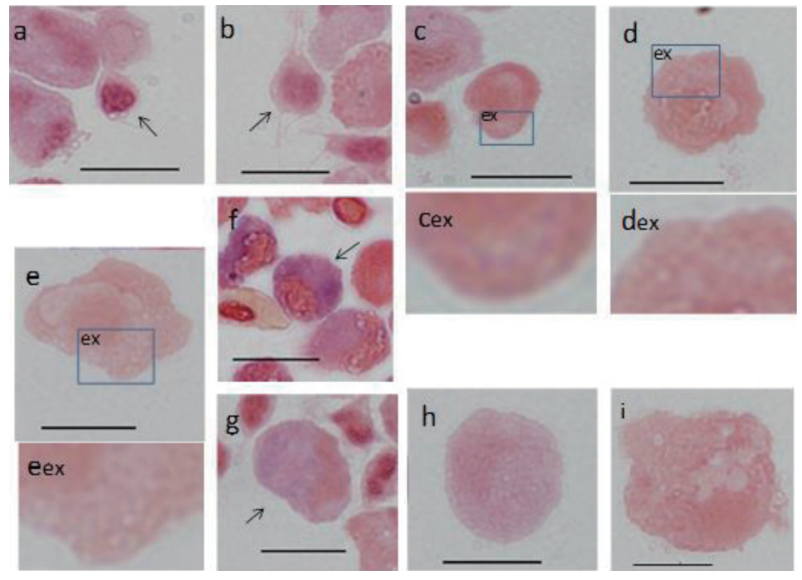

Fig. 6. Cells from peripheral blood (a-h) and spleen (i) of ayu, Plecoglossus altivelis altivelis, after alkaline phosphatase staining. Bar $=10 \mu \mathrm{m}$, ex: magnified image of corresponding box, a: A1 type (arrow), b: A2 type (arrow), c, c $\mathrm{ex}_{\mathrm{ex}}$ : B1 type, d, $\mathrm{d}_{\mathrm{ex}}$ : B2 type, e, ex $\mathrm{ex}_{\mathrm{e}}$ B3 type, f: $\mathrm{C} 1$ type (arrow), g: C2 type (arrow), h: C3 type and i: F type.
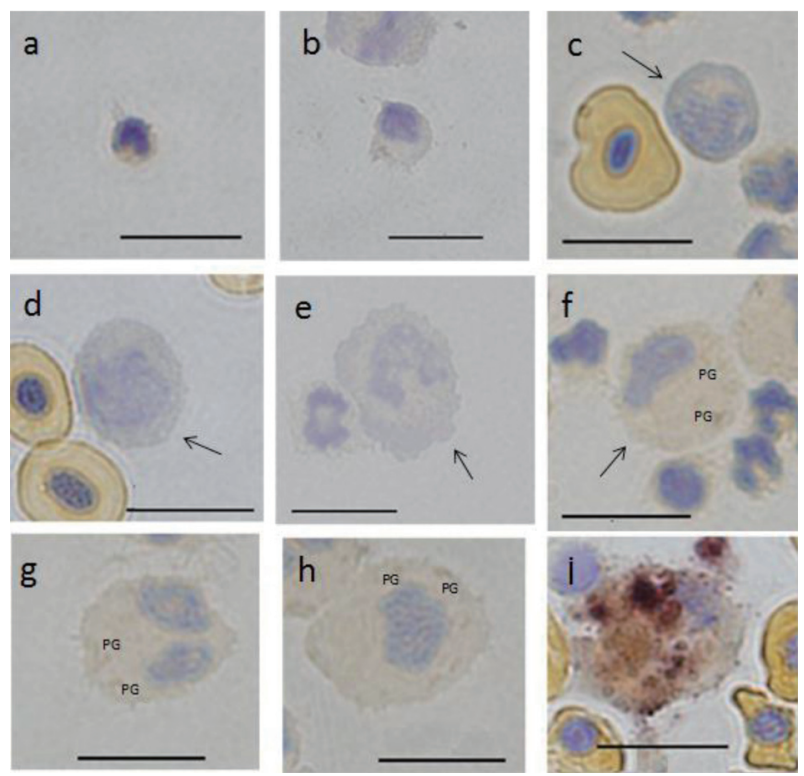

Fig. 8. Cells from peripheral blood (a-h) and spleen (i) of ayu, Plecoglossus altivelis altivelis after esterase ( $\alpha$-naphthyl butyrate method) staining. Bar $=10 \mu \mathrm{m}, \mathrm{PG}$ : positive granule, a: A1 type, b: A2 type, c: B1 type (arrow), d: B2 type (arrow), e: B3 type (arrow), f: C1 type (arrow), g: C2 type, h: C3 type and i: F type (center).

Nuclei were oval (Fig. 1m) or rod-shaped (Fig. 1n) with faint linear packed chromatin.

Percoll density gradient separation of blood cells: The density layers in which blood cells were present comprised $32 \%$ Percoll (SG 1.042) to 60\% Percoll (SG 1.075), and erythrocytes precipitated below the $62 \%$ layer. Peripheral blood was taken from four healthy ayu using heparin, and

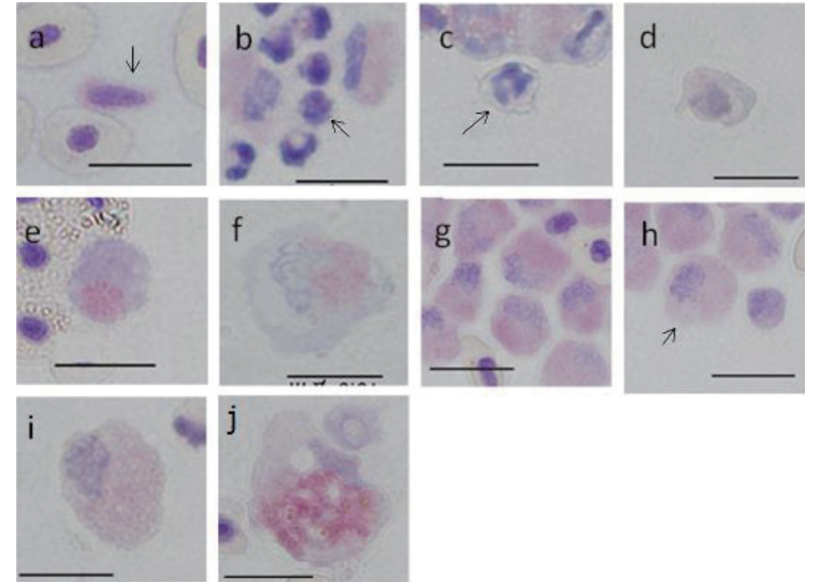

Fig. 7. Cells from peripheral blood (a-i) and spleen (j) of ayu, Plecoglossus altivelis altivelis, after acid phosphatase staining (Bar=10 $\mu \mathrm{m})$. a: Ab type (arrow), b: A1 type (arrow), c: A2 type (arrow), d: B1 type, e: B2 type, f: B3 type, g: C1 type, h: C2 type (arrow), i: $\mathrm{C} 3$ type and $\mathrm{j}$ : F type.
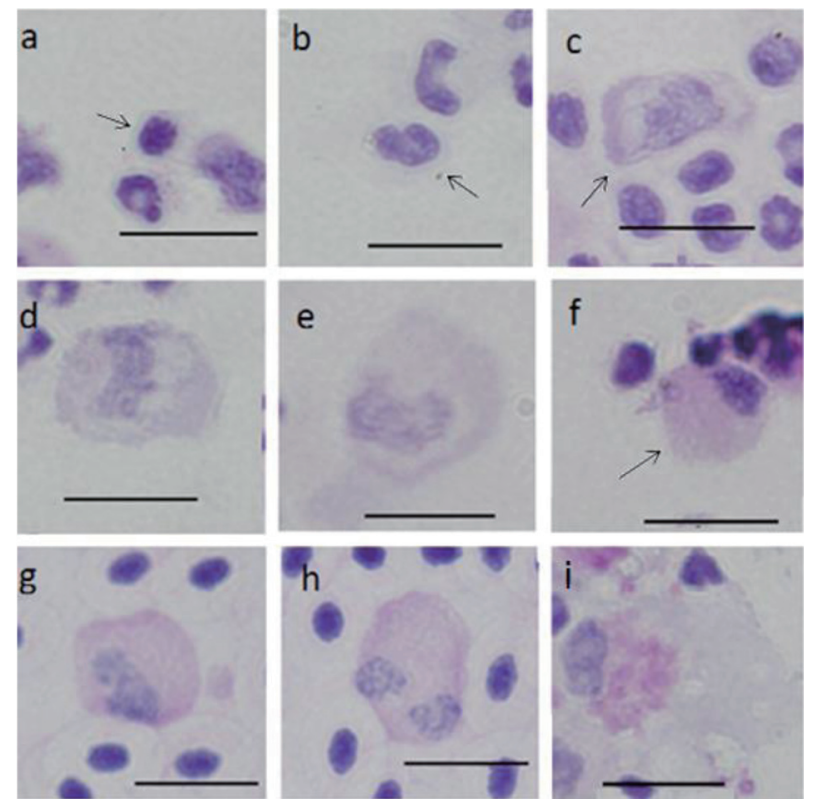

Fig. 9. Cells from peripheral blood (a-h) and spleen (i) of ayu, Plecoglossus altivelis altivelis, after staining with periodic acid Schiff reaction. Bar $=10 \mu \mathrm{m}$, a: A1 type (arrow), b: A2 type (arrow), c: B1 type (arrow), d: B2 type, e: B3 type, f: C1 type (arrow), g: C2 type, h: $\mathrm{C} 3$ type and i: F type.

these samples were mixed. Mixed blood was placed on the Percoll gradient solution and separated by density.

Blood cells seen in each density layer were classified as A, B, C, D and E cells, 60-300 blood cells were counted in each group, and the percentage of each blood cell in each layer was calculated (Table 4). The SG range for A1 and A2 cells 
was 1.042-1.056. For the B group, B1 was isolated at 1.052$1.063, \mathrm{~B} 2$ at 1.059-1.063 and B3 at 1.056-1.061; however, $\mathrm{B} 1$ and B2 were also seen at 1.073-1.075. C group cells were present in higher SG layers; C1 was seen at 1.056-1.059 and 1.070-1.075, while C2 and C3 were seen at 1.059-1.075. $\mathrm{C} 1$ and $\mathrm{C} 3$ were also seen at 1.042-1.045. D cells were only seen at 1.066, and E cells were only seen at 1.063.

$N / C$ rati: The relationship between cell area $(\mathrm{CA})$ and N/C ratio for each white blood cell is shown in Fig. 2a, 2b and 2c. The value of N/C ratio tended to decrease inversely with $\mathrm{CA}$ size in A1, A2, Aa and Ab cells (Fig. 2a). Aa and Ab plots overlapped with A2 plots, and some Aa plots overlapped with A1 plots. Data for B1, B2, B3, E and F are shown in Fig. 2 b. The gradients for B1, B2 and B3 appear to be shifting, and the plot for $\mathrm{E}$ fell on an extended line from the plot for $\mathrm{B} 2$ and $\mathrm{B} 3$. The relationship between $\mathrm{CA}$ and $\mathrm{N} / \mathrm{C}$ ratio for $\mathrm{B}$, $\mathrm{E}$ and $\mathrm{F}$ cells showed an inverse correlation, similarly to $\mathrm{A}$ cells in Fig. 2a. On the other hand, in the plot for F, changes in the value of the $\mathrm{N} / \mathrm{C}$ ratio were uncommon (Fig. 2b). The data for C1, C2, C3 and D are plotted in Fig. 2c, which also shows an inverse relationship. C1, C2 and C3 were divided by cell size, and thus, continuity of the graph is observed. Moreover, D is buried within the plot group for $\mathrm{C} 2$.

Leishman-Giemsa staining ( $L S G$ ): Leishman-Giemsa and MGG are included in Romanowsky staining; therefore, the staining results for LMG resembled those of MGG (Fig. 3). Basophilic cytoplasm in A1 and A2 on LMG staining was blue-violet. The nucleus of A1 was dark purplish-red, while that of A2 was purplish-red (Fig. 3a and 3b).

Toluidine blue staining: Smears were stained with toluidine blue and rinsed in aqueous solutions $\mathrm{pH}$ 1.5, 3.0 and 4.5. Cell images from rinsed smears at $\mathrm{pH} 4.5$ are shown in Fig. 4. Metachromatic cells were not observed in rinsed smears, irrespective of $\mathrm{pH}$.

Peroxidase (PO) staining: The A and B groups were negative. As the after-stain was Giemsa staining, negative cells in the A cells (Fig. 5a and 5b) and B cells (Fig. 5c-5e) showed staining characteristics that were similar to those of MGG. $\mathrm{C}$ cells were peroxidase positive, and whole cytoplasm was stained light brown or brown with a blackish brown granule seen with few cells (Fig. 5f-5h). Rank order of positive activity was $\mathrm{C} 1>\mathrm{C} 2>\mathrm{C} 3$. Cytoplasm in $\mathrm{C} 2$ and $\mathrm{C} 3$ cells showed unstained vacuoles, and the nucleus was dark purple or dark brown with the nucleus being belt-shaped or an aggregated shape (Fig. 5f-5h). Cytoplasm in F cells showed trace levels of dark brown staining (Fig. 5i). D and E cells were not observed in any cytochemically stained smears.

Alkaline phosphatase (ALP): The $\mathrm{A} 1$ and $\mathrm{A} 2$ groups were negative (Fig. 6a and 6b). In B1, B2 and B3 cells, a blue granule near the nucleus showed grade I staining (Fig. 6c-6e). C1 and $\mathrm{C} 2$ cells showed grade IV staining, and many large granules were observed (Fig. 6f and 6g), while C3 cells showed grade III staining (Fig. 6h). Similarly to DAB staining, the rank order of ALP positivity was $\mathrm{C} 1>\mathrm{C} 2>\mathrm{C} 3$. F cells were negative (Fig. 6i).

Acid phosphatase (ACP): A1 and A2 cells showed grade I staining, and the cytoplasm had several red-purple granules with a few dark red-purple granules observed in the nucleus
(Fig. 7a-7c). B1, B2 and B3 cells showed grade III staining, and the cytoplasm showed aggregated granules (Fig. 7d-7f). $\mathrm{C}$ group cells showed grade IV staining, and the cytoplasm was full of small granules (Fig. 7g-7i). F cells showed grade III staining, and large granules with a purple-red staining were observed in about half of the cytoplasm (Fig. 7j).

Nonspecific esterase (EST $\alpha-N B)$ : A and B group cells were negative (Fig. 8a-8e). C group showed slight staining of granules (Fig. $8 \mathrm{f}-8 \mathrm{~h}$ ). F cells showed grade III staining, and the cytoplasm was light reddish-brown with aggregated granules of blackish-brown color (Fig. 8i).

Periodic acid Schiff (PAS) reaction: PAS activity in A1 and A2 cells was negative (Fig. 9a and 9b). Cytoplasm in B cells had several granules of red-purple color showing grade I staining (Fig. 9c-9e). C cells showed grade III staining (Fig. 9f-9h), and granules were scattered throughout the cytoplasm. In particular, a fringe region of cytoplasm showed strong activity. F cells showed grade II staining, and the cytoplasm near the nucleus showed large aggregated granules with red-purple staining (Fig. 9i).

\section{DISCUSSION}

The morphological characteristics of leucocytes and thrombocytes in fish stained with Romanowsky dyes are summarized from previous references in Table $5[7,12,19]$. In many cases, the terms used to describe fish blood cells are borrowed from mammalian hematology due to the morphological similarities. Leucocytes in fish have some overlapping features with those in mammals $[7,12]$. Leucocytes and thrombocytes in ayu are categorized with reference to other fish (Table 6).

Thrombocytes (A type cells): Thrombocytes are readily deformed after blood collecting, and Ikeda et al. [12] sketched the thrombocyte shapes seen at each stage. Aa and $\mathrm{Ab}$ were thrombocytes smeared using the Wedge technique immediately after blood sampling. Ab cells showed a spiked shape, and the morphological changes do not appear to advance. Aa was similar to thrombocytes that showed changes in morphology. The structure of nucleus chromatins was rough in $\mathrm{Aa}$ and was condensed rods in $\mathrm{Ab}$. On the other hand, A1 and A2 cells were obtained by density gradient separation and cytospin. The morphological changes were progressive. Ikeda et al. [12] also showed images of gathered thrombocytes or aggregated cells and designated active thrombocytes. There is a close resemblance between A1 type cells and the cells in Ikeda et al.'s report. The nucleus showed a dark red-purple color and was clearly distinguished from other blood cells. Moreover, the features of aggregated thrombocytes were observed (data not shown). The color of the A2 nucleus after staining MGG was bright when compared with A1. With regard to the differences in these nuclei, Saunders [20] showed that thrombocytes have two staining properties. Although LSG staining was excellent for detection of thrombocytes among other blood cells, the nuclei of thrombocytes after LSG staining showed two distinct colors, similarly to MGG staining (Fig. 3). The most important morphological characteristic of A2 cells was the 
Table 5. Morphplogical characteristics of blood cells from fish [7, 12, 19]

\begin{tabular}{|c|c|c|c|c|}
\hline Cell type & Form of a cell & Cytoplasm & Nucleus & Notes \\
\hline Thrombocyte & $\begin{array}{l}\cdot \text { Spiked, spindle, oval or } \\
\text { one-nucleus shape }[7,12] \\
\cdot \text { Morphological change } \\
\text { by artificial manipulation. } \\
\text { (round, oval) }[12] \\
\cdot \text { Pseudopodia by stimulation } \\
{[12]} \\
\cdot \text { Many reports of several } \\
\text { species [12] }\end{array}$ & $\begin{array}{l}\text { - Blue in immature and } \\
\text { grayish blue in mature [7] } \\
\text { Granules: young deeply } \\
\text { basophilic, intermediate light } \\
\text { basophilic }[7,19]\end{array}$ & $\begin{array}{l}\cdot \text { Ribbed arranged chromatin } \\
{[7]} \\
\cdot \text { Indented heterochromatin } \\
\text { which transverse the nucleus } \\
{[19]}\end{array}$ & \\
\hline Lymphocyte & $\begin{array}{l}\cdot \text { Round or oval shape [12] } \\
\cdot \text { From small to large cell } \\
{[12]} \\
\text { - Produce a pseudopodia by } \\
\text { stimulation [12] }\end{array}$ & $\begin{array}{l}\cdot \text { Narrow cytoplasm [12] } \\
\cdot \text { Blue, graish blue, light blue } \\
\text { cytoplasm [12] } \\
\cdot \text { Azurophilic granules in } \\
\text { cytoplasmic also sometimes } \\
\text { seen [17] } \\
\cdot \text { Golgi field [12] }\end{array}$ & $\begin{array}{l}\text { Roughly condensed chro- } \\
\text { matin [12] and dense patched } \\
\text { heterochromatin [19] } \\
\cdot \text { Round shape [12] } \\
\cdot \text { Many cells have cleaved or } \\
\text { constriced parts [12] } \\
\cdot \text { Occasional nucleus [19] }\end{array}$ & $\begin{array}{l}\text { Resemble to human cell } \\
\text { Plasma cells have been } \\
\text { found in the peripheral blood } \\
\text { of many fish [19] }\end{array}$ \\
\hline Neutrophil & $\begin{array}{l}\text { - Round or oval shape* }[7 \text {, } \\
12]\end{array}$ & $\begin{array}{l}\text { - Basophilic color (immature } \\
\text { form), light blue, greyish } \\
\text { blue and light red cytoplasm } \\
{[12]} \\
\cdot \text { Colorless granules, dark } \\
\text { gray, gray granules, light } \\
\text { red, bluish red, purplish-red } \\
\text { small granules [7, 12] } \\
\text { - Two types of granules are } \\
\text { formed in immature and } \\
\text { mature goldfish [19] }\end{array}$ & $\begin{array}{l}\cdot \text { Round,oval,lobe } \\
\text { kidney,horseshoe }[7,12] \\
\cdot \text { Several lobes }(2-5)^{*}[7,12]\end{array}$ & \\
\hline Basophil & - Round shape* [12] & $\begin{array}{l}\text { - Basophilic cytoplasm [19], } \\
\text { light red, dark bluish purple } \\
\text { granule* [12] } \\
\text { - Light brown cytoplasm } \\
\text { (carp,crucian carp) [12] } \\
\text { - Pansy large granule } \\
\text { (carp,crucian carp) }[12]\end{array}$ & $\begin{array}{l}\cdot \text { Densely stained nucleus } \\
{[12]} \\
\cdot \text { Ambiguous chromatin net } \\
{[12]}\end{array}$ & $\begin{array}{l}\text { Rare appearance }[12] \\
\text { It is easy to release a } \\
\text { granule by water and alcohol } \\
{[12] .}\end{array}$ \\
\hline Eosinophil & - Round or oval shape* [12] & $\begin{array}{l}\cdot \text { Vermeil-red large granule* } \\
{[12]} \\
\cdot \text { Beige granule (freshwater } \\
\text { fish) [12] } \\
\cdot \text { Vermeil-red granule } \\
\text { (seawater fish) }[12]\end{array}$ & $\begin{array}{l}\text { Sausage-shaped or bilobed } \\
\text { eccentric nucleus [19] } \\
\cdot \text { Rough condensed and } \\
\text { reticulated chromatin* }[12]\end{array}$ & $\begin{array}{l}\text { Easy cytolysis under } \\
\text { unsuitable specimen } \\
\text { preparation [12] }\end{array}$ \\
\hline $\begin{array}{l}\text { Monocyte/ } \\
\text { macrophage }\end{array}$ & $\begin{array}{l}\cdot \text { Most large cell in leuco- } \\
\text { cytes } *[12] \\
\cdot \text { Oval, irregular or amoe- } \\
\text { boid } *[12] \\
\cdot \text { Pseudopodium [12] }\end{array}$ & $\begin{array}{l}\text { - Basophlilic, gray, bluish } \\
\text { purple cytoplasm* [12] } \\
\cdot \text { Basophilic color at im- } \\
\text { mature form [12] } \\
\text { - Scattered purplish red } \\
\text { granule around nucleus* [12] } \\
\text { - Agranular gray-blue } \\
\text { cytoplasm [19] } \\
\text { - Vesicle/vacuoles and } \\
\text { inclusion [19] } \\
\text { - Golgi field does not exist* } \\
{[12]}\end{array}$ & $\begin{array}{l}\text { Round, kidney type or } \\
\text { irregular bilobe* }[12] \\
\cdot \text { Rough condensed and linear } \\
\text { chromatin* }[12]\end{array}$ & $\begin{array}{l}\text { - Resemble to human cell } \\
{[12]}\end{array}$ \\
\hline
\end{tabular}

*: Characteristic of human blood.

homogeneous nucleus chromatin. As this characteristic was also seen in A1, nucleus chromatin probably changed as a result of Percoll density separation (Fig. 1a and 1b). On density gradient separation, A1 and A2 cells were collected from density $1.042-1.047$, but B1 and C1 cells were markedly separated from A1 and A2 cells (Table 4).

Lymphocytes (B type cells): Cytoplasm of B1 cells in the case of MGG was blue or light blue and had a Golgi-like field and nucleus with rough condensed chromatin. B1 cells thus have typical features of lymphocytes (Tables 5 and 6). The roughly condensed chromatin in B1 cells was a major difference from the homogeneously packed chromatin in A cells and was an important point of distinction among small blood cells. On the other hand, numerous B2 and B3 cells 
Table 6. Morphological characteristics of cells from peripheral blood and spleen in ayu, Plecoglossus altivelis altivelis

\begin{tabular}{|c|c|c|c|c|c|}
\hline $\begin{array}{l}\text { Part of col- } \\
\text { lected sample } \\
\text { blood cell }\end{array}$ & $\begin{array}{l}\text { Cell } \\
\text { type }\end{array}$ & & Morphology & Cytoplasm & Nucleus \\
\hline Caudal vein & $\begin{array}{l}\mathrm{A} 1 \\
\mathrm{~A} 2 \\
\mathrm{Aa} \\
\mathrm{Ab}\end{array}$ & $\begin{array}{l}\text { Thrombocyte } \\
\text { Thrombocyte } \\
\text { Thrombocyte } \\
\text { Thrombocyte }\end{array}$ & $\begin{array}{l}\text { A1:round,spindle } \\
\text { A2:round,oval } \\
\text { Aa:round or bean-shape } \\
\text { Ab:spiked } \\
\text { A1:aggregated } \\
\text { A1,A2:pseudopodia }\end{array}$ & $\begin{array}{l}\cdot \text { A1:gray,light blue-purple } \\
\cdot \text { A2:gray,light blue-purple, light } \\
\text { blue } \\
\cdot \text { Aa,Ab:colourless, gray or light } \\
\text { blue-purple } \\
\cdot \text { Ab: gray or light blue-purple }\end{array}$ & $\begin{array}{l}\cdot \text { A1:dark purplish-red, } \\
\text { Aa:purplish-red, A2,Ab:light } \\
\text { purplish-red } \\
\cdot \text { A1:round or spindle, A2: round, } \\
\text { kidney-shape or horseshoe-shape, } \\
\text { Aa::round or bean-shape, Ab:rod- } \\
\text { shape } \\
\cdot \text { A1, A2:homogeneously packed } \\
\text { chromatin } \\
\text { - Aa, Ab: faint rough condensed } \\
\text { chromatin }\end{array}$ \\
\hline Caudal vein & B1 & Lymphocyte & $\begin{array}{l}\text { B1:round, oval or } \\
\text { bean-shape } \\
\text { B1:small cell }\end{array}$ & $\begin{array}{l}\text { - Blue or light blue } \\
\cdot \text { Golgi field }\end{array}$ & $\begin{array}{l}\text { - Round or oval } \\
\text { - Rough condensed chromatin but } \\
\text { indistinct chromatin net }\end{array}$ \\
\hline Caudal vein & $\begin{array}{l}\mathrm{B} 2 \\
\mathrm{~B} 3\end{array}$ & $\begin{array}{l}\text { Lymphocyte } \\
\text { Lymphocyte }\end{array}$ & $\begin{array}{l}\text { B2,B3:round, oval } \\
\text { B2,B3middle,large cell } \\
\text { B2,B3:pseudopodia }\end{array}$ & $\begin{array}{l}\cdot \text { Blue-gray or light blue } \\
\cdot \text { Colorless vesicles } \\
\cdot \text { Golgi field }\end{array}$ & $\begin{array}{l}\text { - Kidney-shape, horseshoe-shape, } \\
\text { or infinite-shape } \\
\text { - Rough condensed chromatin. }\end{array}$ \\
\hline Caudal vein & $\begin{array}{l}\mathrm{C} 1 \\
\mathrm{C} 2 \\
\mathrm{C} 3\end{array}$ & $\begin{array}{l}\text { Neutrophil } \\
\text { Neutrophil } \\
\text { Neutrophil }\end{array}$ & $\begin{array}{l}\cdot \text { Round or oval } \\
\cdot \text { Small large cell }\end{array}$ & $\begin{array}{l}\cdot \text { Light blue gray or light peach } \\
\text { gray } \\
\cdot \text { Invisible granules }\end{array}$ & $\begin{array}{l}\text { - Round, spindle, kidney-shape or } \\
\text { rod-shape } \\
\cdot \text { Bilobed nuclei } \\
\cdot \text { Rough condensed chromatin } \\
\cdot \mathrm{C} 1 \text { :faint rough condensed } \\
\text { chromatin }\end{array}$ \\
\hline Caudal vein & $\mathrm{D}$ & Basophil & - Oval & $\begin{array}{l}\cdot \text { Light blue-gray and light red in } \\
\text { part } \\
\cdot \text { Large blue-purple granules }\end{array}$ & $\begin{array}{l}\cdot \text { Kidney-shape } \\
\cdot \text { Large blue-purple granules on } \\
\text { nucleus } \\
\cdot \text { Unclear chromatin net }\end{array}$ \\
\hline Caudal vein & $\mathrm{E}$ & $\begin{array}{l}\text { Monocyte/ } \\
\text { Macrophage }\end{array}$ & $\begin{array}{l}\cdot \text { Large cell } \\
\cdot \text { Oval } \\
\cdot \text { Pseudopodia }\end{array}$ & $\begin{array}{l}\cdot \text { Light blue gray } \\
\cdot \text { Blue granules, dark red-purple } \\
\text { stained inclusions and vesicles/ } \\
\text { vacuole } \\
\cdot \text { Invisible Golgi-like field }\end{array}$ & $\begin{array}{l}\cdot \text { Kidney-shape } \\
\cdot \text { Lineal packed chromatin }\end{array}$ \\
\hline Spleen & $\mathrm{F}$ & $\begin{array}{l}\text { Monocyte/ } \\
\text { Macrophage }\end{array}$ & $\begin{array}{l}\text { - Large cell } \\
\text { - Round, oval or } \\
\text { amoeboid-shape } \\
\text { - Pseudopodia }\end{array}$ & $\begin{array}{l}\text { - Light blue gray } \\
\text { - Black-blue or black-brown stained } \\
\text { inclusions and vesicles/ vacuoles } \\
\text { - Invisible Golgi field }\end{array}$ & $\begin{array}{l}\text { - Oval, kidney, rod or amorphous } \\
\text { - Lineal packed chromatin but } \\
\text { indistinct chromatin net }\end{array}$ \\
\hline
\end{tabular}

showed altered morphology similarly to B1 cells. B2 and B3 cells were round or spindle-shaped with some cells having cytoplasmic pseudopodia. The cytoplasm in the case of MGG was blue-gray or light blue and included colorless vesicles. The nuclei were kidney-shaped, horseshoe-shaped or infinity-shaped. Features similar to monocytes/macrophages were seen, but these are more likely to be lymphocytes because basophilic cytoplasm and a Golgi-like field are observed. We use the term Golgi-like field in this paper, and although more detailed staining is necessary, we used this term because the staining indicated that this area was the Golgi field.

Granulocytes (C and D type cells): C1, C2 and C3 cells were round or oval, and their cytoplasm in the case of MGG was gray, light blue-gray or light peach-gray with no granules. Nuclei were round, spindle-shaped, kidney-shaped or rod-shaped with rough condensed chromatin, and bilobed nuclei were also seen. These typical features are indicative of neutrophils (Tables 5 and 6). Small $\mathrm{C} 1$ cells may have therefore been mistaken for other blood cells. When cell area decreases, cytoplasm becomes relatively small and the ratio occupied by the nucleus increases. $\mathrm{C} 1$ neutrophils with faint rough chromatin were seen, and this makes identification of neutrophils and thrombocytes difficult. Therefore, it was necessary to use PO staining, etc., for identification, in addition to MGG staining. By performing PO staining in parallel to MGG, Yuki [22] has advocated that the changes in blood cell composition of fish can be expressed rationally. On the other hand, for identification of basophils or eosinophils, the presence of basophilic or eosinophilic granules is indispensable. For basophilic granules, Suzuki [21] noted basophilic material combined with basic dye was readily extruded, even in extremely diluted electrolyte solution; therefore, dilution of dyes with distilled water is essential for retention of the granules in MGG stain. This study used MGG staining with the same procedure, and few D cells from ayu were recognized. As D cells had basophilic granules, they were considered to be basophils. In addition, cells showing metachromasia in the peripheral blood after toluidine blue 
Table 7. Cytochemical reactivity of blood cells from ayu, Plecoglossus altivelis altivelis, and several teleosts [4-6, 8-10, 14, 15, 21]

\begin{tabular}{|c|c|c|c|c|c|c|c|c|c|c|c|c|c|}
\hline \multirow{2}{*}{$\begin{array}{l}\text { Cytochemical } \\
\text { reaction }\end{array}$} & \multirow{2}{*}{ Fish species } & \multicolumn{2}{|c|}{ Thrombocyte } & \multicolumn{2}{|c|}{ Lymphocyte } & \multicolumn{2}{|c|}{ Neutrophil } & \multicolumn{2}{|c|}{ Basophil } & \multicolumn{2}{|c|}{ Eosinophil } & \multicolumn{2}{|c|}{$\begin{array}{c}\text { Monocyte/ } \\
\text { Macrophage }\end{array}$} \\
\hline & & C.R. & [Ref.] & C.R. & [Ref.] & C.R. & [Ref.] & C.R. & [Ref.] & C.R. & [Ref.] & C.R. & [Ref.] \\
\hline \multirow[t]{13}{*}{$\mathrm{PO}$} & Plecoglossus altivelis altivelis & - & & - & & + & & & & & & $-\sim \pm$ & \\
\hline & Cyprinus carpio & - & [8] & - & {$[4,9]$} & + & {$[21]$} & - & {$[21]$} & & &,-+ & {$[4,9]$} \\
\hline & Carassius auratus & - & [8] & - & [9] & & & & & & & + & [9] \\
\hline & Carassius carassius & - & [8] & & & & & & & & & + & [9] \\
\hline & Ictalurus punctatus & - & [5] & & & + & 5 & & & & & - & {$[5]$} \\
\hline & Salmo irideus & - & [8] & - & [9] & & & & & & & + & [9] \\
\hline & Anguilla anguilla & - & [8] & - & [9] & & & & & & & + & [9] \\
\hline & Takifugu vermicularis & & & & & + & [21] & - & {$[21]$} & & & & \\
\hline & Takifugu niphobles & & & & & + & {$[10]$} & & & - & {$[10]$} & & \\
\hline & Takifugu rubripes & & & & & + & {$[10]$} & & & - & {$[10]$} & & \\
\hline & Lates japonicus & & & - & [15] & + & {$[15]$} & & & - & {$[15]$} & - & {$[15]$} \\
\hline & Chelon haematocheilus & & & - & [14] & + & [14] & & & & & - & {$[14]$} \\
\hline & Pleuronectes platessa L. & & & & & + & {$[6]$} & & & & & & \\
\hline \multirow[t]{10}{*}{ ALP } & Plecoglossus altivelis altivelis & - & & \pm & & + & & & & & & - & \\
\hline & Cyprinus carpio & - & [8] & - & {$[9]$} & - & {$[22]$} & - & {$[21]$} & & & \pm & [9] \\
\hline & Carassius auratus & - & [8] & - & [9] & & & & & & & - & [9] \\
\hline & Carassius carassius & & & & & & & & & & & - & [9] \\
\hline & Salmo irideus & - & [8] & - & [9] & & & & & & & \pm & [9] \\
\hline & Anguilla anguilla & + & [8] & + & [9] & & & & & & & - & [9] \\
\hline & Takifugu vermicularis & & & & & - & {$[21]$} & - & {$[21]$} & & & & \\
\hline & Lates japonicus & & & \pm & [15] & + & {$[15]$} & & & - & {$[15]$} & \pm & {$[15]$} \\
\hline & Chelon haematocheilus & & & - & [14] & - & {$[14]$} & & & & & + & {$[14]$} \\
\hline & Pleuronectes platessa $L$. & & & & & + & {$[6]$} & & & & & & \\
\hline \multirow[t]{10}{*}{ ACP } & Plecoglossus altivelis altivelis & \pm & & + & & + & & & & & & + & \\
\hline & Cyprinus carpio & + & [8] & & & + & {$[21]$} & + & {$[21]$} & & & + & [9] \\
\hline & Carassius auratus & \pm & {$[8]$} & \pm & [9] & & & & & & & + & [9] \\
\hline & Carassius carassius & \pm & {$[8]$} & \pm & [9] & & & & & & & + & [9] \\
\hline & Salmo irideus & + & {$[8]$} & - & [9] & & & & & & & + & [9] \\
\hline & Anguilla anguilla & - & {$[8]$} & - & [9] & & & & & & & + & [9] \\
\hline & Takifugu vermicularis & & & & & + & {$[21]$} & + & {$[21]$} & & & & \\
\hline & Lates japonicus & & & \pm & [15] & + & {$[15]$} & & & \pm & {$[15]$} & + & {$[15]$} \\
\hline & Chelon haematocheilus & & & + & [14] & + & {$[14]$} & & & & & + & {$[14]$} \\
\hline & Pleuronectes platessa L. & + & [6] & & & + & {$[6]$} & & & & & + & [6] \\
\hline \multirow[t]{5}{*}{$\mathrm{ES}(\alpha-\mathrm{NB})$} & Plecoglossus altivelis altivelis & - & & - & & \pm & & & & & & + & \\
\hline & Cyprinus carpio & & & & & + & {$[21]$} & \pm & {$[21]$} & & & & \\
\hline & Takifugu vermicularis & & & & & + & {$[21]$} & - & {$[21]$} & & & & \\
\hline & Lates japonicus & & & - & [15] & + & {$[15]$} & & & - & {$[15]$} & - & {$[15]$} \\
\hline & Chelon haematocheilus & & & - & {$[14]$} & \pm & {$[14]$} & & & & & + & {$[14]$} \\
\hline \multirow[t]{10}{*}{ PAS } & Plecoglossus altivelis altivelis & - & & \pm & & + & & & & & & + & \\
\hline & Cyprinus carpio & + & {$[8]$} & & & & & + & {$[21]$} & & & + & [9] \\
\hline & Carassius auratus & + & {$[8]$} & + & [9] & & & & & & & + & [9] \\
\hline & Carassius carassius & + & {$[8]$} & + & [9] & & & & & & & + & [9] \\
\hline & Salmo irideus & + & {$[8]$} & + & [9] & & & & & & & + & [9] \\
\hline & Anguilla anguilla & + & {$[8]$} & + & [9] & & & & & & & + & [9] \\
\hline & Takifugu vermicularis & & & & & & & - & {$[21]$} & & & & \\
\hline & Lates japonicus & & & \pm & [15] & + & {$[15]$} & & & \pm & {$[15]$} & \pm & {$[15]$} \\
\hline & Chelon haematocheilus & & & \pm & [14] & + & {$[14]$} & & & & & + & {$[14]$} \\
\hline & Pleuronectes platessa L. & \pm & {$[6]$} & \pm & {$[6]$} & + & {$[6]$} & & & & & + & {$[6]$} \\
\hline
\end{tabular}

PO:Peroxidase, ALP: Alkaline phosphatase, ACP: Acid phosphatase, EST ( $\alpha$-NB):Esterase ( $\alpha$-naphthyl butyrate), PAS: Periodic acid Schiff reaction, C.R.: Cytochemical reactivity, Ref.: References. 
Table 8. Cytochemical activity of human leukocytes [16]

\begin{tabular}{|c|c|c|c|c|c|c|}
\hline & Thrombocyte $^{\text {a) }}$ & Lymphocyte ${ }^{\text {b) }}$ & Neutrophil & Basophil & Eosinophil & Monocyte \\
\hline MPO & & - & + & $-\sim+$ & + & $-\sim+$ \\
\hline NAP & & - & 0 & - & - & - \\
\hline $\mathrm{ACP}$ & & $\pm \sim+$ & + & + & + & + \\
\hline $\operatorname{EST}(\alpha-\mathrm{NB})$ & & $-\sim+$ & - & + & $-\sim+$ & + \\
\hline PAS & & \pm & + & + & + & + \\
\hline
\end{tabular}

MPO: Myeloperoxidase, NAP: Neutrophyl alkaline phosphatase, ACP: Acid phosphatase, EST ( $\alpha$-NB): Esterase ( $\alpha$-naphthyl butyrate), PAS: Periodic acid Schiff reaction. a) No data, b) Expressed B,T and NK lymphcytes.

staining were not recognized. There are very few basophils in the peripheral white blood of ayu. Eosinophils were not observed in the peripheral white blood, and this may be because they are scarce or do not exist. However, we observed the cells derived from peripheral white blood cell fraction using Percoll density gradient. Eosinophilic or basophilic cells may exist in another fraction.

Monocytes/macrophages (E and F cells): Fish monocytes/ macrophages are the largest leucocytes. Cytoplasm in the case of MGG is light blue-gray, and the Golgi-like field is not present. Moreover, granules and vessels/vesicles are seen in the cytoplasm (Table 5). E and F cells in peripheral blood or spleen from ayu had these features (Fig. 11-1n), and as the Golgi-like field was not seen in the cytoplasm, they could be distinguished from lymphocytes. However, monocytes/macrophages (E cells) were scarcely present in ayu peripheral blood, which was only $0.1 \%$ leucocytes (Table 2). Ellis [6] reported monocytes in smears from normal plaice (Pleuronectes platessa) blood, accounting for about $0.1-0.2 \%$ of the total white blood cells, including thrombocytes. The eccentric nucleus of monocytes in plaice typically occupied less than half of the cell and was often notched or horseshoe-shaped with loosely arranged chromatin. Macrophages from plaice can be considered to consist of three main types: free round cells (free macrophages), fixed macrophages and melano-macrophages. In addition, free macrophages were observed in smears of kidney, spleen, thymus, mesentery and peritoneal fluid. They had a wide size range. The nucleus was eccentric and typically round with loosely packed chromatin. The abundant cytoplasm was only slightly basophilic on Romanowsky staining, and vacuoles were sometimes present. Darkly stained inclusions were sometimes seen and considered to be phagocytozed debris. It is possible that the nucleus of E cells from ayu peripheral blood whose $\mathrm{N} / \mathrm{C}$ ratio is 0.25 (Table 1 ) is smaller than the nucleus of monocytes from plaice peripheral blood [6]. The $\mathrm{N} / \mathrm{C}$ ratio of monocytes/macrophages ( $\mathrm{E}$ and $\mathrm{F}$ cells) is small and differs from other cells that show very little change in N/C ratio value, even if the size of CA is different (Fig. 2b). Thus, not only F cells from spleen, but E cells from peripheral blood have similar features as free macrophages from plaice.

Cytochemical staining: Cytochemical staining is used to detect illnesses related to blood (clinical hematology) or as an additional means of identifying blood cell type. As described above, the differential blood cells from ayu were already identified based on morphological features by Romanowsky staining. The A group cells were thrombocytes, the B group cells were lymphocytes, the $\mathrm{C}$ group cells were neutrophils, the D cell were basophils, and the $\mathrm{E}$ and $\mathrm{F}$ group cells were monocytes/macrophages. Cytochemical features of differential leucocytes and thrombocytes from ayu and data on several types of teleost are summarized in Table 7 [4-6, 8-10, 14, 15, 21]. Furthermore, the cytochemical features of leucocytes from human blood are shown in Table 8 [16].

Some enzymatic activity in leucocytes from ayu using cytochemical techniques closely resembled that of human cells (Tables 7 and 8). Although staining activity of blood cells from teleosts showed similar reactions, some differences were noted. On PO staining, ayu and teleost thrombocytes and lymphocytes were negative, and neutrophils were positive (Table 7). In human blood, ALP is expressed as neutrophil alkaline phosphatase and shows specific positivity in neutrophils. Although ALP in neutrophils from ayu is positive, negative neutrophils are seen in other teleosts. The ALP reactions in thrombocytes, lymphocytes and monocytes/macrophages show various degrees of staining activity between fish.

Other than thrombocytes and lymphocytes, ACP shows the positive staining in all teleosts. Although nonspecific EST $\alpha$-NB has few measurement examples, neutrophils are positive or weakly positive in all teleosts, and monocytes/ macrophages are positive in ayu, but negative staining is seen in some fish. PAS is positive or weakly positive in all blood cells from most teleosts, but thrombocytes from ayu were negative.

There are few specific cytochemical reactions for thrombocytes and lymphocytes from ayu. Ayu thrombocytes show weak positivity for cytoplasm, but deep red granules next to the nucleus are seen on ACP staining. Ellis reported the same results for plaice thrombocytes [6]. This may be useful for cytochemically identifying thrombocytes.

Lymphocytes from ayu showed positivity on ACP staining and weak positivity on ALP and PAS staining. Based on morphological characteristics by Romanowsky staining, B2 and B3 cells were identified as lymphocytes. Although B2 and B3 cells were stained similarly to B1 cells on cytochemical staining by ACP and PAS, monocytes/macrophages were different from B cells. Although the identification of blood cells is also possible based on slight differences in staining, some results are indistinct on obtained images with ALP or 
PAS staining, and further examination is necessary.

C cells from Ayu showed specific positivity on PO, ALP, $\mathrm{ACP}$ and PAS staining. This suggests that $\mathrm{C}$ cells are neutrophils.

For monocytes/macrophages ( $F$ cells) from ayu spleen, EST $\alpha$-NB was specifically positive, while ALP and PAS were positive and PO was weakly positive. However, the weak positivity for PO in monocytes/macrophages may originate from phagocytozed substances [2]. Activation of macrophage occurs via the classical pathway (progenitors - monocytes - mature macrophages) or the alternate pathway (mature macrophages appear to rapidly develop from early progenitors in the absence of an intermediate monocyte stage) [3]. Three distinct sub-populations (R1, R2 and R3) of macrophages derived from goldfish kidney-leukocyte cultures were generated and characterized by Neumann et al. [17]. Rl macrophages were small cells that contained ACP, but lacked PO and non-specific EST ( $\alpha$-naphthyl acetate esterase). R2 macrophages were morphologically similar to mature tissue macrophages from mammals, while R3 macrophages resembled mammalian monocytes. The R2 and R3 cells stained for ACP, PO and non-specific EST [3, 17]. Thus, monocytes/macrophages appear to show different staining properties with differentiation and maturation. The cytochemical activities of monocytes/macrophages from ayu spleen seem to resemble the results for R2 or R3 cells, but PO activity was unclear. Monocytes/macrophages from ayu peripheral blood showed morphological similarities. However, there are no cytochemical data for monocytes/ macrophages from ayu peripheral blood, and these will be necessary for further observation.

ACKNOWLEDGMENT. The author is grateful to the members of the Takahashigawa Fish Farming Laboratory for their care and maintenance of the experimental fish.

\section{REFERENCES}

1. Anami, K. 1991. Esterase Senshoku, Kousosenshoku II, pp. 272-275. In: Ketsuekikensa, Sin Senshokuhou no Subete., Medical Technology. Betsusatsu Ishiyaku Shupann Kabushikigaisha, Tokyo (in Japanese).

2. Afonso, A., Silvia, J., Lousada, S., Ellis, A. E. and Silva, M. T. 1998. Uptake of neutrophils and neutrophilic components by macrophages in the inflamed peritoneal cavity of rainbow trout (Oncorhynchus mykiss). Fish Shellfish Immunol. 8: 319-338. [CrossRef]

3. Belosevic, M., Hanington, P. C. and Barreda, D. R. 2006. Development of goldfish macrophages in vitro. Fish Shellfish Immunol. 20: 152-171. [CrossRef] [Medline]

4. Bielek, E. 1981. Developmental stages and localization of peroxidatic activity in the leucocytes of three teleost species (Cypri- nus.carpio L.; Tinea tinea L.; Salmo gairdneri Richardson). Cell Tissue Res. 220: 163-180. [CrossRef] [Medline]

5. Cannon, M. S., Mollenhauer, H. H., Cannon, A. M., Eurell, T. E. and Lewis, D. E. 1980. Ultrastructural localization of peroxidase activity in neutrophil leukocytes of Ictalurus punctatus. Can. J. Zool. 58: 1139-1143. [CrossRef] [Medline]

6. Ellis, A. E. 1976. Leucocytes and related cells in the plaice, Pleuronectes platessa. J. Fish Biol. 8: 143-156. [CrossRef]

7. Ellis, A. E. 1977. The leucocytes of fish, A review. J. Fish Biol. 11: 453-491. [CrossRef]

8. Fey, F. 1965. Vergleichende hämozytologie niederer Vertebraten II. Thrombozyten. Folia Haematol. (Frankf.) 85: 205-217.

9. Fey, F. 1966. Vergleichende hämozytologie niederer Vertebraten IV. Monozyten-plasmozyten-lymphozyten. Folia Haematol. (Frankf.) 86: 133-147.

10. Hamaguchi, M., Usuki, H. and Ishioka, H. 1992. Classification of blood cells of Tiger Puffer, Takifugu rubripes, and Grass Puffer, Takifugu niphobles. Bull. Nansei Nati.Fish Res. Inst. 25: 51-58.

11. Hirano, M., Katsuta, I., Ino, A., Okamoto, A., Ikemoto, A., Akiyama, H., Mizoguchi, Y. and Gunzi, A. 2006. p. 386. Visual Rinshou Ketuekikeitaigaku. Nankoudou,Tokyo (in Japanese).

12. Ikeda, Y., Ozaki, H. and Hamazaki, K. 1986.p. 361 Blood Atlas of Fishes. Midarishobou, Tokyo (in Japanese).

13. Katano, O., Umino, T. and Taniguchi, S. 2011.Ayu no Tsuri to Kagaku. pp. 1-275. Gakuhousha (in Japanese).

14. Kondo, M., Yasumoto, S. and Takahashi, Y. 2011. Morphological and cytochemical characteristics of leukocytes from Redlip Mullet, Chelon haematocheilus. J. Natl. Fisheries Univ. 59: $173-178$.

15. Kondo, M., Yasumoto, S. and Takahashi, Y. 2012. Staining Characteristics of Lymphocyte, Monocyte and Eosinophil from Japanese Lates, Lates japonicus. J. Natl. Fisheries Univ. 60: 95-102.

16. Matsuno, K. 2004.Haketsukyu, pp.26-34, In: Ketuekikensahou, Standard Kensa Ketsuekigaku, The Japanese Society for Laboratory Hematology.Ishiyaku Shupann Kabushikigaisha, Tokyo (in Japanese).

17. Neumann, N. F., Barreda, D. R. and Belosevic, M. 2000. Generation and functional analysis of distinct macrophage subpopulations from goldfish (Carassius auratus L.) kidney leukocyte culture. Fish Shellfish Immunol. 10: 1-20. [CrossRef] [Medline]

18. Ogawa, K. and Muroga, K. 2012. Kaitei Gyobyougaku Gairon. p. 192, Kouseishakouseikaku, Tokyo (in Japanese).

19. Rowley, A. F., Hunt, T. C., Page, M. and Mainwaring, C. 1988. Fish. pp. 19-127. In: Vertebrate Blood Cells (Rowley, A.F. and Ratcliffe, N.A.eds.), Cambridge University Press, New York.

20. Saunders, D. C. 1968. Vartations in thrombocytes and small lymphocytes found in the circulating blood of marine fishes. Trans. Am. Microsc. Soc. 87: 39-43. [CrossRef] [Medline]

21. Suzuki, Y. 1986. Cytochemistry of Basophil Granulocyte in Carp and Puffer. Bull. Jpn. Soc. Sci. Fish 52: 1895-1899. [CrossRef]

22. Yuki, R. 1963. A comment of microscopic examination of the blood cell constituents in fish. Bull. Japan Soc. Sci. Fish 29: 1098-1103. [CrossRef] 